\title{
Culture et technologie : une robinsonnade
}

\section{Britta Rupp-Eisenreich}

\section{OpenEdition}

Journals

Édition électronique

URL : https://journals.openedition.org/tc/846

DOI : $10.4000 /$ tc. 846

ISSN : 1952-420X

\section{Éditeur}

Éditions de l'EHESS

\section{Édition imprimée}

Date de publication : 1 mars 1988

ISSN : 0248-6016

\section{Référence électronique}

Britta Rupp-Eisenreich, "Culture et technologie : une robinsonnade», Techniques \& Culture [En ligne], 10 | 1988, mis en ligne le 23 janvier 2006, consulté le 29 septembre 2022. URL : http:// journals.openedition.org/tc/846; DOI : https://doi.org/10.4000/tc.846

Ce document a été généré automatiquement le 29 septembre 2022

Tous droits réservés 


\section{Culture et technologie : une robinsonnade}

Britta Rupp-Eisenreich 